\title{
Sexually transmitted retribution
}

\section{A history of attitudes towards sinning and its consequences.}

\author{
The Wages of Sin: Sex and \\ Disease, Past and Present \\ by Peter Lewis Allen \\ University of Chicago Press: 2000. 202 pp. \\ $\$ 25, \mathfrak{E} 17.50$
}

\section{W. F. Bynum}

Have you noticed how many dust-jackets these days carry recommendations from Roy Porter? Four of the five books I took to the Canaries last November carried the Porter Seal of Approval. Two of the three books I am using in a course I am teaching this autumn have Porter puffs; he edited the third one.

The dust-jacket of Peter Allen's new book has the following by Porter: "Quite the best survey there is of the sad history of love and disease, sex and sin. Peter Allen writes with panache and compassion." Well, yes and no. This series of case studies of historical attitudes towards the relationship between disease and sin is a good read. It is engaging and intensely personal, with a moving autobiographical introduction that identifies the author as a gay Jewish male one of whose earliest lovers died in his arms from AIDS.

Allen also attempts to see both sides of his story. Christianity has been instrumental in defining sin within Western culture for the past two millennia; most of those whom Allen singles out as eager to cast first stones, or to associate disease with sin and sufferers with just punishment, were certain that God was on their side. Christianity is not the only religion to castigate the sex-for-fun brigade, but for those Allen writes about, and writes for, it is the dominant moulder of values, especially within the born-again United States. (An angry Muslim, Hindu or Jew could have told much the same story as Allen, within different cultural contexts.)

Most of Allen's bad guys are thus Christians. But so are most of his good guys and women. While highlighting the religious origins of prudery and fear of the body and its sexual functions, he also recognizes that Christianity can be a religion of compassion and healing. He appreciates the religious origins of hospitals and the ministrations of those who cared for sufferers of leprosy, syphilis and bubonic plague in times past, and who minister to people with AIDS today. He even has sympathy for Saint Augustine, one of the key players in the evolution of negative Christian attitudes towards the human body, perhaps because even Augustine could famously pray for chastity and continence, but "not just yet".

The dichotomy that Allen seeks to analyse is most subtly exposed in the first (and best) chapter, on lovesickness. This disorder,

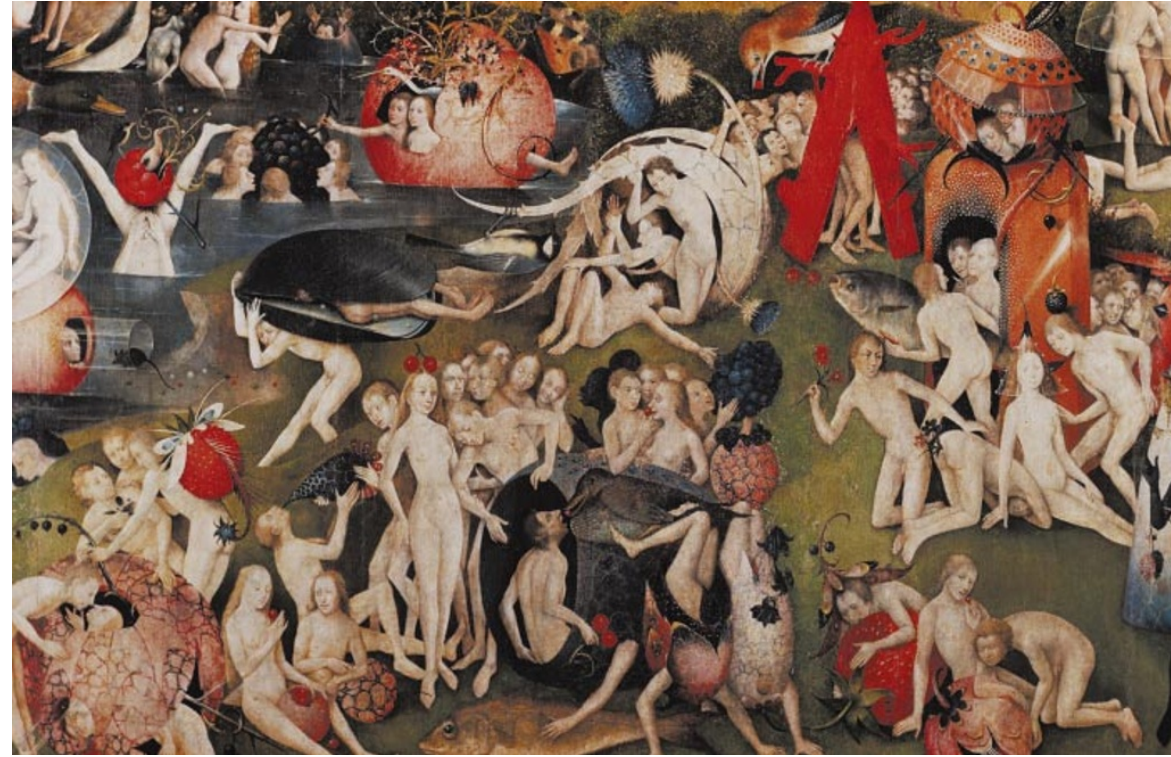

Pleasure before pain: Hieronymus Bosch's Garden of Delights(1503-04).

clearly described by the Greeks, could affect men and women of all ages, though of course it was more common before old age. Caused, among other things, by unrequited love or a fixation on some love object, it led to listlessness, loss of appetite, melancholy and, sometimes, death. For the Greeks, the treatment was unproblematic: sex. For medieval Christians, steeped in a culture that agreed with Saint Paul that marriage is only marginally better than burning, and sex outside marriage a deadly sin, what was a doctor to prescribe after diagnosing lovesickness? If his patient was unmarried, marriage might work. But what if his patient was already married and the source of this ailment was not his or her spouse? A few hardy doctors argued for following Greek precedent, but theologians thundered against the very notion of coition as cure.

After lovesickness, Allen offers us the standard group of diseases that, for a variety of historical reasons, have been singled out for stigmatization: leprosy ('the disease of the soul') and plague, for example, which were often associated with non-sexual sin. But for the most part Allen is interested in the consequences of sexual indiscretion, including an interlude on the consequences of masturbation. He has a good eye for the occasional novel quotation, but also a wonderful tendency to rediscover the wheel at frequent intervals along the way.

There are two substantial problems with this book. One is its very familiarity. Allen's central theme was dredged up repeatedly in the early 1980s, when AIDS was new. Maybe it does all need saying again, but I thought we were pretty familiar with the 'diagnosis as moral judgement' motif, with homosexuality medicalized and then publicly demedicalized in the past couple of decades. And what is 'lifestyle' medicine if not moral medicine? There is pretty good epidemiological evidence that many of the seven deadly sins can cause disease. (The nicest one is probably sloth, but even that can lead to cardiovascular problems.)

The second problem with Allen's book is that it is simply too much about the present. All history reflects the writer's present, and some historians (and sociologists) go so far as to suggest that history is only about the present. This book would be grist to their mills. Allen makes too many specious and intrusive comparisons between plagueridden London and AIDS-ridden San Francisco, between medieval churchmen ostracizing lepers and Ronald Reagan refusing to mobilize American medical might against AIDS. Both were lamentable, but historians need to do more than simply draw shrill parallels.

For all of its admirable qualities, then, Allen's book doesn't stand up very well as history. I think he would probably be a witty and charming dinner companion, however. So, just as we are supposed to hate sin but love the sinner, we can value what he tells us about the contemporary United States even while he is writing about syphilis in sixteenthcentury Italy.

W. F. Bynum is at the Wellcome Trust Centre for the History of Medicine, University College London, 24 Eversholt Street, London NW1 1AD, UK. 